\title{
Cytoplasmic Vacuolation
}

National Cancer Institute

\section{Source}

National Cancer Institute. Cytoplasmic Vacuolation. NCI Thesaurus. Code C96302.

A morphologic finding referring to the presence of vacuoles within the cytoplasm of the cells. 